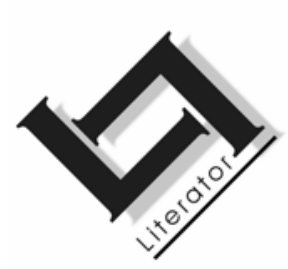

\title{
Echoes of orality in Christian Xhosa songs
}

\author{
M.M. Somniso
}

School of Language, Media and Communication

Nelson Mandela Metropolitan University

PORT ELIZABETH

E-mail: Michael.somniso@nmmu.ac.za

\begin{abstract}
Echoes of orality in Christian Xhosa songs

This article is an attempt to investigate and explore certain patterns in traditional Christian Xhosa songs as found in Xhosa music. The corpus of contemporary Xhosa music is vast, and difficult to explore properly without recognising the patterns of traditional music. In order to recognise these patterns Xhosa music in general will be discussed first - Xhosa music also as a form of art. Having done that, it will try to uncover certain elements of traditional songs in Christian Xhosa music. A comparative approach will be used to reveal the similarities between traditional and Christian songs. To compare certain aspects in a literary work does not imply attaching more significance to one element than to another. This method rather implies a way of looking beyond narrow boundaries, and to explore other spheres of human activities.
\end{abstract}

\section{Opsomming}

\section{Eggo's van oraliteit in Christelike Xhosa-liedere}

Hierdie artikel is 'n poging om sekere patrone wat in tradisionele Christelike Xhosa-liedere en Xhosa-musiek aangetref word, te ondersoek en te verken. Die korpus hedendaagse Xhosa-musiek is omvangryk en moeilik om behoorlik te ondersoek sonder om kennis te neem van die patrone wat in tradisionele musiek aangetref word. Ten einde hierdie patrone te kan uitken, sal die soeklig aanvanklik val op Xhosa-musiek in die algemeen en sal dit ook as kunsvorm bespreek word. Daarna sal daar gepoog word om die elemente van tradisionele liedere in Christelike Xhosa-musiek bloot te lê. 'n Vergelykende benadering sal gebruik word om die ooreenkomste tussen tradisionele en Christelike liedere aan te 
toon. 'n Vergelyking tussen sekere aspekte van literêre werke bring nie noodwendig mee dat die een teen die ander afgespeel word nie - dit is eerder 'n manier om buite eng begrensings te kyk en om ander gebiede van menslike aktiwiteit te ondersoek.

\section{Introduction}

With regard to the concept music Hamm (1975:1) says there are many types of music in the world, and these types of music differ just like the cultures in which they are found. The individuality and uniqueness of a form of music may be traced to many things such as the composer and the society that gave birth to it. The acoustic material used to perform the music, and the specific manner in which it is performed are of great importance. The nature of music can also change over time as a result of social, political and religious factors. The interplay between African and European traditions, for example, sometimes results in the use of Western instruments such as concertinas and guitars when African traditional songs are sung. This kind of performance is commonplace today. Hamm (1975:104) further states that African Americans have lost their original music through the break-up of their tribal groups and the Westernised environment in which they live.

The nature of Xhosa music also varies very much today because of dramatic socio-political changes among the Xhosa people. The nature of Xhosa music varies because modern theatres and marketing organisations operate according to specifications laid down relating to the promotion of any branch of music. Xhosa traditional music has never been actively promoted through marketing, because it is meant to entertain the community, and has never been intended for commercial purposes. Although Xhosa music varies even in itself, the quality of beauty and purpose remain. In this respect Xhosa traditional music can be regarded as having been modified in order to suit certain situations.

Xhosa traditional music was never meant to be performed indoors, but today it is performed in both in-door and out-door environments. Xhosa traditional music, as an art form, was meant to entertain society at large (at a time when there were no halls to accommodate large audiences). This is therefore one of the reasons why performances among the amaXhosa often took place in the open air. According to Somniso (2002:119) nowadays some music is exclusively sung in churches and schools - also by the amaXhosa. This kind of music is conditioned by the acoustic requirements of churches and schools - a relatively new development in the 
traditional life of the amaXhosa. This kind of music is well received by amaXhosa who have adopted it as their own. Apart from music used in churches and schools, there is also a very popular type of music known as "urban music", that among others, includes jazz and kwaito. In a way, contact with other racial and tribal groups as well as Westernisation have resulted in certain changes in the traditional forms of Xhosa music. Tracey (1961:10) thus comments on change: "change, gradual change, one must not forget, is [an] abiding factor in all music".

A change of patterns in music should be welcomed rather than rejected. Unchanging traditional music today is the product of static and isolated communities. The most important thing is that all music is based primarily upon traditional music. This means that church, school and urban music among the amaXhosa are largely the products of African people. For example, school and church music will at all times resemble traditional music among the amaXhosa. During the colonial period, traditional music was eroded and not appreciated on its own merits.

Traditional songs have recently started to receive more attention in literary studies. Somniso (2002), for instance, deals with aspects of oral literature in Christian songs. For the purposes of this article it is necessary to contextualise traditional songs, and then to discuss such songs as a form of art.

\section{Traditional songs as a form of art}

In virtually all societies, people experience the need to express their feelings and ideals in what we might call an artistic medium. The expression of feelings and ideals can perhaps be regarded as the central function of visual performances, music, dance, and folklore. Anthropologists and other social scientists refer to these activities as forms of expressive culture (Ember \& Ember, 1990:455). Visual performances of songs sometimes include the representation of folklore of which traditional songs form part. A historical approach also places traditional songs within a traditional setting. In traditional African societies music making is generally organised as a social event. According to Nketia (1975:21-23) public performances take place on social occasions when members of a community come together for enjoyment, for recreational activities, or for the performance of a rite, ceremony, festival, or any kind of collective activity. In industrialised societies songs are sometimes sung and performed when a bridge or railway line is built. The basis for music making, however, is usually the community, among members who 
share a common place such as homesteads or villages, and who live some kind of corporate life. The performance of traditional music in such contexts, therefore, assumes a multiple role in relation to the community.

The corpus of African traditional music is vast, and communicates a message of sorrow, anger, inspiration and love. The nature and the scope of music are generally related to the aims of a specific social event. African music has, to a great extent, been informal. It is therefore that one observes certain elements of African traditional music in formal Xhosa music. Some of these elements such as repetition and rhyme are also found in Christian Xhosa songs. It is therefore important to discuss the types and nature of Christian Xhosa songs. Such an approach will help to identify the essential qualities or characteristics inherent in traditional Xhosa songs.

\section{Types and nature of Christian Xhosa music}

According to Somniso (2002:123), Christian Xhosa music is a subtype of Xhosa music, and can further be divided into specific genres such as hymns, amakhorasi (music phrases), gospel and Zionist music. The sketch below illustrates a general classification of Xhosa music:

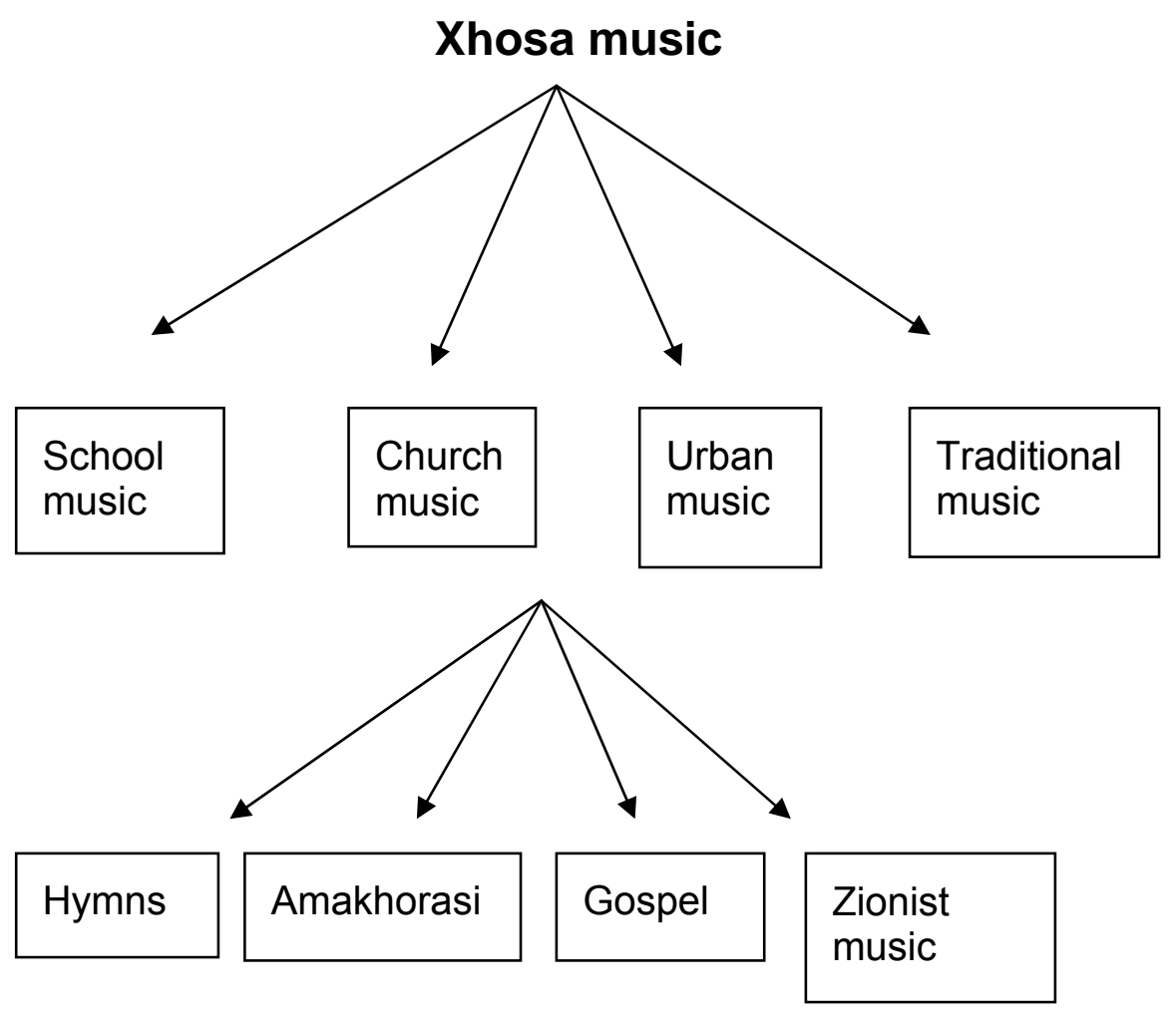


In this illustration it is clear that there are four types of Christian Xhosa music: hymns, amakhorasi, gospel and Zionist music. This article will focus particularly on amakhorasi and Zionist music, and will also use Ntsikana's hymns as references when necessary. According to Hodgson (1980:1-2) Ntsikana was the son of Gaba who was a hereditary councillor to Ngqika. Ntsikana is linked to the beginnings of Christianity among the amaXhosa. He is remembered for preparing the way for the gospel among the amaXhosa during the early nineteenth century, and is revered by many Africans as a prophet and a saint. Ntsikana composed four hymns which were woven into the liturgy used in his services. Singing Ntsikana's hymns was accompanied by traditional dances. The reason for using Ntsikana's hymns in this article is that they lend themselves to the traditional style when they are sung. Amakhorasi and Zionist songs are oral by nature and simple to use in worship services. They are also meant to be sung by everybody in church during church gatherings. These songs are very popular among the amaXhosa and some of these Christian Xhosa songs have been recorded by the Department of African languages at the Nelson Mandela Metropolitan University.

The themes of amakhorasi and Zionist songs are religious in nature and express, among other things, the love of God/Jesus, hope, happiness, healing and praising. These songs are sung during Christian gatherings, whether formal or informal. Preachers also use these songs during their sermons to raise the spirits of their followers. When these spiritual songs are sung, the aura of traditional songs is prevalent within them. It is therefore important to discuss the influence of traditional songs upon Christian music.

\section{The influence of African traditional songs on Christian music}

Independent churches such as the Zion Church of Christ and the United Methodist Church of Southern Africa have long ago terminated their relations with their colonial masters. It is against this background that these churches no longer adhere to the European style of singing. Other churches, such as the Zion Church of Christ, compose their own church music that reflects African elements. The music used in these churches is accompanied by instruments and dance. Some mainline churches, among others the Uniting Presbyterian Churches and the African Evangelical Church, have also adopted the African style of singing. The African style of singing finds to a great extent expression in the way in which amakhorasi 
are sung. The nature of amakhorasi is similar to that of traditional music. According to Muirhead (1982:95-96) the church has never been free from the influence of traditional music. Traditional elements can also be indicated in Gregorian chants and Lutheran hymns. Muirhead also states that through the ages there has been opposition to the blending of secular and sacred music. Changes of any nature are experienced as threatening by certain individuals. Even among amaXhosa there are still those who believe that the incorporation of traditional musical elements into Christian music reduces the solemnity of the service. Forms of worship are also extensively expressed in music. For the amaXhosa the nature of music need not contain Western elements in order to be relevant for today. According to Courlander (1963:35) Afro-American Christian songs include a wide range of styles, idioms and substance.

Amakhorasi and Zionist songs have also been altered to conform to the nature of African traditional music. Amakhorasi adapted as Christian songs include elements of traditional music and are sung purely in a traditional way. Traditional songs are concerned, among other things, with social practices such as marriage and initiation. Amakhorasi and Zionist songs, on the other hand, express the feeling of the society in which these songs have been created from a Christian angle. Amakhorasi and Zionist songs reflect the attitudes and aspirations of Christians, whilst traditional songs mark and celebrate social change. The following ikhorasi, for example, encourages Christians to pray as they have been set by God on earth to subdue and have dominion over it.

Ikhorasi:

Thandaza, nob'indlel' inameva, thandaza.

(Pray even if the road has thorns, pray.)

In the following traditional song, the family of the girl to be married expresses concern about her life in her new home and also makes an appeal to her in-laws to look after her.

Zenimphathe kakuhle, usisi wethu, az' angalambi,az'azangadlakazeli.

(Look well after our sister, she should not starve, she should not be ragged.) 
The underlying factor is that both types of songs are sung to mark social change or to celebrate. Regarding Zionist songs Dargie $(1988: 32)$ claims that

[t]hese songs among Xhosa Zionists (include both rural and urban areas) include songs in traditional style, and also show the same Western and extraneous African influences as some of the Gqobhoka songs.

lingoma zikaNtsikana (Ntsikana's hymns) are examples of church music that has integrated both Western and traditional styles. Ntsikana conducted services for his converts, taught them what he had learnt about Christianity in an African way, and composed songs for their services. "Ulo Thixo Omkhulu" is an example of one of his hymns. These versions of songs are sung in an overall traditional manner (Dargie, 1988:4-5). Ntsikana's hymns must have been strongly influenced by traditional styles, because he was a renowned Xhosa singer, dancer and poet. In his hymns he interprets Christianity by drawing among other things, on the images, symbols and literary forms characteristic of Xhosa tradition.

Features like parallelism, repetition and rhyme can be observed in the following stanza of Ntsikana's hymn "Ulo Thixo oMkhulu":

Ulo Thixo oMkhulu, ngoseZulwini;

Unguwena-wena Khaka leNyaniso.

Unguwena-wena Nqaba yeNyaniso.

Unguwena-wena Hlathi leNyaniso.

(He is the Great God, who is in Heaven;

Thou art Thou, Shield of Truth.

Thou art Thou, Stronghold of Truth.

Thou art Thou, Forest of Truth.)

(Hodgson, 1980:19.)

According to Milubi (1988:28), parallelism implies the correspondence in sense or construction of successive clauses or passages. Furthermore in each pair of lines the first halves are identical in wording and are basically similar in meaning. Somniso (2002:104) is of the opinion that repetition can entail repetition of sounds, words, verses, thoughts, and syllables. Parallelism and repetition are important aspects common among iimbongi (traditional praise singers). Rhyme inter alia implies an association of words with similar sounds, a technique often used in songs. The above stanza is characterised by initial linking in lines $2,3,4$, and 5 - a tecnique that creates musical rhythm and rhyme. Both line 2 and 4 use 
nyaniso (truth) as rhyming word in the end position of the line. Figurative language is also used in this stanza. Words such as ikhaka (shield), ihlathi (forest) and inqaba (fort) are used metaphorically to refer to God as Protector and Defender of mankind. In some Xhosa churches Christians prefer church music that appeals to their cultural traditions. Ntsikana became one of the initiators of change with regard to Christian music. Significantly, the initiator of change relates, among other things, to the way in which Ntsikana changed Western hymns to accommodate an African style of music. Ndlovu (1994:7) also believes that Zionist churches have already taken Ntsikana's work even further. They have already built a bridge between Christianity and traditional religion by reintegrating elements found in the latter. Amakhorasi represent action songs in the church, like isawundi/isitibili in the context of schools. In schools more formal music such as choral music is used. As formal music churches have hymns.

It is against this background that a comparative approach is used to determine the differences and similarities between traditional songs on the one hand, and amakhorasi and Zionist songs on the other. Through comparison the nature of similarities or differences between traditional Xhosa songs and Christian Xhosa songs will be indicated (in this article Christian songs will refer to amakhorasi and Zionist songs). The table below shows an example of a traditional song and a khorasi. The aim is to compare them in order to highlight the similarities and differences.

\begin{tabular}{|c|c|c|c|}
\hline \multicolumn{2}{|c|}{ Traditional song } & \multicolumn{2}{|l|}{ Inhorasi } \\
\hline Umhlabeli: & Tsho $\ldots$ tsholoza! & Umhlabeli: & $\begin{array}{l}\text { Ngubanin' ofana } \\
\text { noJesu! }\end{array}$ \\
\hline $\begin{array}{l}\text { (Lead } \\
\text { singer: }\end{array}$ & Move ... on ) & $\begin{array}{l}\text { (Lead } \\
\text { singer: }\end{array}$ & $\begin{array}{l}\text { Who is like } \\
\text { Jesus) }\end{array}$ \\
\hline Abanye: & $\begin{array}{l}\text { Tshotsholoza! } \\
\text { kwezondawo! }\end{array}$ & Abanye: & $\begin{array}{l}\text { Ngubanin' } \\
\text { ofana Naye! }\end{array}$ \\
\hline (Chorus: & $\begin{array}{l}\text { Move on to those } \\
\text { places!) }\end{array}$ & (Chorus: & Who is like Him) \\
\hline Bonke: & $\begin{array}{l}\text { Sitimela sibhek' } \\
\text { eRhodesia! }\end{array}$ & Bonke: & Woza, woza! \\
\hline (Group: & $\begin{array}{l}\text { The train is going to } \\
\text { Rhodesia) }\end{array}$ & (Group: & Come, come!) \\
\hline
\end{tabular}


Observation:

- Both songs make use of the same pattern of singing - umhlabeli (lead singer), abanye (chorus) and bonke (group).

- Repetition of words occur - in the traditional song tshotsholoza is repeated in lines 1 and 2 . In the ikhorasi the words Ngubanin' ofana are also repeated in lines 1 and 2.

- Both songs use different concepts in line 3.

- The way of singing both songs is cyclic in nature.

The above information confirms the influence of traditional songs on amakhorasi. The similarities reflected above point to the relationship between traditional songs and amakhorasi. Other similarities will be illustrated during the discussion of composition, the use of instruments, and themes implemented in amakhorasi. Christian songs are composed by people who practise them as will be illustrated in the next part of the discussion.

\section{The composition of Christian Xhosa songs}

During the period of the missionaries Xhosa hymns were mainly based upon translated European hymns. The translation of European hymns into Xhosa presented a huge problem as the text sometimes became distorted. The Xhosa language is tonal and tone is important in determining meaning. In singing, therefore, the rising and falling tones of speech generally influence the melody and even direct its course, if the sense is to be retained. Often, in the transposition of the translated texts into European hymn-tunes, it was felt that the text became distorted because of the disregard of intonation.

Early compositions were based on the possibility of translating the hymns. In 1850 John Bowke and Tiyo Soga began to compose their own music. Their music comprised hymn-tunes and sacred songs of the type in vogue in Victorian England. The music of these early composers hardly had any merits, as they were merely taught the rudiments of the music via tonic solfa. Moreover, the music they produced was far removed from the traditional Xhosa music. Bokwe and Tiyo Soga tried without success to address this problem, but they were not allowed to compose African hymns.

As opposed to Bokwe and Soga, a contemporary composer, Tyamzashe, tried to be African in his approach to music structure as well as in his composition. In Inkulungwane yeBhayibhile yesiXhosa 
(1959) (the 100th anniversary of the Xhosa/English Bible) for instance, he utilises parallelism, which is a characteristic of indigenous Xhosa music. This element gave his music a more African flavour (Hansen, 1968:26-30). The composition of Christian hymns by early Xhosa composers was undertaken to produce new hymns and songs, but also to incorporate cultural values likely to create rhythm, and the songs would eventually culminate in a dance.

The art of composing traditional songs among amaXhosa is guided by social customs. Any person can, for instance, compose songs, but these songs are not written down and do not accommodate dancing. Similar characteristics can also be indicated in amakhorasi and Zionist songs as they are also not written down by their composers. Both types of songs developed very quickly, as many Xhosa people have the ability to compose. The umhlabeli (lead singer) could also introduce a new khorasi or a Zionist song which he/she may have heard in another congregation. When amakhorasi are sung they are accompanied by instruments.

\section{The use of accompaniment}

The emergence of amakhorasi as an art form did not replace hymns, but is rather a functional evolution in Christian Xhosa music. Amakhorasi serve a practical function in the sense that they are sung in church, but carry the banner of Xhosa traditional songs. When these spiritual songs are sung, percussive effects such as clapping hands, stamping feet, and the use of instruments are incorporated. The use of instruments is very common among amaXhosa. The aim is to add sound to the human voice or the stamping of feet. For example, in traditional societies instruments such as iimpempe (whistles), iifluthi (flutes) amaphondo (horns), amahadi (bows), ikatari (guitar) and iikloko (rattles) are used by boys when they are dancing. Igubu (drum) and whistle are commonly used by diviners. Traditional women play uhadi (bow) and wear ankle rattles when they sing and dance. Some of the instruments mentioned previously can be used in churches and will be discussed briefly below. The aim is to highlight the overlapping use of some of these instruments.

The following instruments are sometimes used in some mainline churches and in most independent churches: tambourines/rattles, triangles, cowbells, umpampampas (Bible-sized cushion covered with leather), drums, sound pipes. 
Tambourine/rattle: A tambourine has a horseshoe shape and contains metal rings which produce the sound. Rattles have the same function, but are different from a tambourine, because rattles can be worn around the ankle, for example, by boys. Rattles are given different names by amaXhosa, for example ikloko, oonokhenkce or oonokroxo. In Zionist churches worshippers also make their own rattles/tambourines by making holes in a polish tin, and putting small stones inside it in order to make a sound when it is shaken. According to the Good News Bible a tambourine is a small drum with pieces of metal in the rim, held in the hand and then shaken. Tambourines were also used by women. To support this notion Judges 11:34 serves as an illustration: when Jephthah went back home to Mizpah, his daughter came out to meet him, dancing and playing the tambourine.

Triangle: The triangle is an instrument of steel bent into a threesided form. It is usually held by a string on the left hand and struck with a small bar of iron or steel with the right hand (Stainer, 1989:447).

Cowbell: This instrument is like a small school bell, and an iron rod is used to beat it. The shape of the bell housing is flat or round.

Umpampampa: An umpampampa is a Bible-sized cushion covered with leather. It is held in one hand and beaten with the other. This is done to produce more sound and to regulate the rhythm.

Drums: There are many kinds of drums. The type of drum depends on the people themselves. Ugandan drums, Tanzanian hand drums, and Atumpan drums can for instance be used. Among the amaXhosa a similar drum is called igubu. The drum is open on both sides and these sides are covered by animal skin. Two sticks are used to beat the drum on the sides. Among amaXhosa this drum is mostly used by Zionist and diviners. Boys use it as well.

Sound pipes: It is an instrument which is blown, and is similar to a trumpet. To improvise sound pipes a pool pipe is sometimes used to make this instrument. According to Hamm (1975:111) African (Hamm uses the term "native") instruments are sometimes used to perform Westernised music, but the instrument utilised for the widest range of music styles is the valiha (tube zither) of Madagascar. South Africans sometimes use home-made instruments such as the igubu (drum).

Listening to the sound of these instruments can evoke the spirit of oral tradition and one can experience the richness of Xhosa oral songs. In some churches Christians have gone further in blending 
Christian songs with traditional music. The use of instruments differ from church to church. The Methodist Church of Southern Africa, for example, sing the same khorasi as the Uniting Presbyterian church, but in their case they are not allowed to use instruments. Amakhorasi as a type of Christian Xhosa songs, should be seen as filling a vacuum in Xhosa churches. These songs represent the African spirit that has been missing. Some Xhosa people left their mainline churches and joined independent churches, the reason being that independent churches allow Xhosa traditional music. Amakhorasi and Zionist songs are typically African. Christian songs, like their counterparts, carry messages. The themes of Christian songs will be discussed under the next heading.

\section{Themes of Christian songs}

The themes of Christian songs relate to Christianity. Most of these songs explore the dichotomy between God and Satan/good and evil. Some of these themes recount earlier Biblical events, for example Kungegazi (It is through blood). In the Bible it is stated that one of the soldiers plunged his spear into Jesus' side, and immediately blood and water poured out (John 19:33). This song suggests that it is through Jesus' blood that we were forgiven our sins. The event of Jesus' crucifixion brought us salvation because our sins were washed away by His blood. Other themes are more generalised and express the idea of death, painting a picture of life after death and sounding a warning to sinners. The most important thing is that these songs provide inspiration for social events or sermons. For example, the following song is a call to everyone to seek salvation:

Shiy' umhlaba nento zawo,

Shiy' umhlaba nento zawo.

Thabath' umnqamlezo ulandele,

Thabath' umnqamlezo ulandele.

(Leave the earth with its problems,

Leave the earth with its problems.

Take the cross and follow,

Take the cross and follow.)

The above song warns people who live in darkness. It proposes that in order to see the light (to be saved), they must forget earthly pleasures and follow Jesus as an example. In Matthew 4:12-18 when Jesus walked along the shore of Galilee He saw two brothers, Simon and Andrew, and He ordered them to leave their fishing nets and follow Him. Jesus wanted his followers to leave everything and be fishers of men. 
The manner in which some people suffer on earth before death is illustrated in the following song:

Ngokuya babesemhlabeni,

Babelila, inyembezi.

Bebandezelwe zizilingo,

Umlingi engaphezi.

(During that time they were still on earth

they were shedding tears of

frustrated oppression,

but the Devil did not stop.)

To suffer as a Christian is regarded as a painful test of one's Christianity. Some people are ridiculed because they are Christians. The following song suggests that such people should be glad because after their suffering the glory of God will be revealed to them. It should also be noted that other Christian songs stress moral pressure to be exercised on sinners or stray sheep, and attempt at converting the sinners. In one of the Zionist songs Jesus is depicted as "colourful" (Umabalabal' uJesu). Jesus was given all authority in heaven and on earth. This suggests that Jesus has power over everything, including human beings. Jesus can also share the Good News with outcasts. Themes in Xhosa songs vary according to the group. A song sung by women will, for example, address the concerns of women, whilst a song sung by Christians will address Christian concerns.

\section{Conclusion}

The nature of Christian Xhosa songs can be summarised as follows (cf. Somniso, 2002:159):

- Christian Xhosa songs are cyclic in form: each song is built up by constant repetitions of (rhythmically) the same cyclic pattern; each cycle in each voice part is a sung sentence composed of phrases.

- The sentences in the text fit the sung cyclic pattern.

- Songs comprise patterns overlapping leader and follower cycles, and are supplemented by parallel harmonically equivalent parts.

As evidenced in this article the above forms also apply to Christian songs. The cantor in Christian songs always determines the tempo. A change of tempo will be determined by slow or fast clapping of hands. Christian and traditional songs share similar characteristics, and both are concerned about aspects of human life. Thematically both types of song are the inspiration of social life. Both types of 
songs are also characterised by a variety of themes that could include, love, beauty, joy, duties, good and evil.

Comparatively seen, amakhorasi, Zionist and traditional songs share great similarities. These similarities are clearly illustrated in songs such as "Tshotsholoza" and "Ngubani ofana noJesu" (Who is like Jesus), in which the repetition of words and sentences reveals congruence. The repetition of phrases such as "Tshotsholoza kwezondawo" and "Ngubani ofana noJesu", enhances the harmonious nature of African music.

There are subtle differences between traditional songs and amakhorasi. These differences are evident in the themes that are utilised: traditional songs express social concerns, whereas amakhorasi recount Biblical events. Biblical jargon is also prevalent in amakhorasi whereas in traditional songs this is not the case. In amakhorasi words such as Jesu (Jesus) and umnqamlezo (cross) are, for example, often used.

It is clear that the characteristics of traditional songs and amakhorasi, which have been discussed in this article, are not diametrically opposed to one another, leading to the conclusion that amakhorasi form part of the evolutionary process of traditional Christian Xhosa songs and Christian music.

\section{List of references}

BIBLE. 1993. Good News. Cape Town: National Book Printers.

COURLANDER, H. 1963. Negro folk music. New York: Colombia University Press.

DARGIE, D. 1988. Xhosa music, its techniques and instruments, with a collection of songs. Cape Town: David Philip.

EMBER, C.R. \& EMBER, M. 1990. Anthropology. New Jersey: Prentice Hall.

HAMM, C.E. 1975. Contemporary music and music cultures. London: PrenticeHall.

HANSEN, D. 1968. The life of Benjamin Tyamzashe a contemporary Xhosa composer. Grahamstown: Rhodes University Press.

HODGSON, J. 1980. Ntsikana the Great Hymn: a Xhosa expression of Christianity in the early 19th-century Eastern Cape. Cape Town: University of Cape Town Printers.

MILUBI, N.A. 1988. Aspects of Venda poetry: a reflection on the development of poetry from the oral tradition to the modern forms. Qwaqwa: University of the North. (Ph.D. thesis.)

MUIRHEAD, J.M. 1982. The religious music of the twentieth-century charismatic renewal in Africa. Pretoria: University of South Africa. (Ph.D. thesis.)

NDLOVU, L. 1994. Healing and trance: a study of conversion in the Zionist church. Pretoria: University of South Africa. (M.A. dissertation.) 
NKETIA, J.H.K. 1975. The music of Africa. London: Lowe \& Brydone.

SOMNISO, M.M. 2002. The incidence of oral literature in selected Xhosa Christian performances. Port Elizabeth: University of Port Elizabeth.(D.Litt. thesis.)

STAINER, J. 1989. Stainer and Barrett's dictionary of music terms. London: Novello.

TRACEY, H. 1961. The evolution of African music and its function in the present day. Public lecture under auspices of ISMA.

\section{Key concepts:}

Christian Xhosa songs

oral elements in traditional Xhosa songs

traditional songs

\section{Kernbegrippe:}

Christelike Xhosa-liedere

orale elemente in tradisionele Xhosa-liedere

tradisionele liedere 
